\title{
ASPECTS OF ASSESSMENT OF STUDENTS' ACTIVITY IN THE SEMINAR CLASSES: PROBLEMS AND SOLUTIONS
}

\author{
Natalia Burlacu*, ORCID ID: 0000-0003-3281-3834 \\ Technical University of Moldova, Faculty of Computers, Informatics and Microelectronics, \\ 9/7 Studentilor street, Chisinau city, Rep. Moldova, MD-2020 \\ *Corresponding author: Burlacu Natalia, natalia.burlacu@iis.utm.md
}

Received: 11, 6, 2021

Accepted: 12, 02, 2021

\begin{abstract}
Given paper is presented as a theoretical-applied study that falls within the scientific dimensions of the theory and methodology of didactic evaluation. The author uses descriptive and analytical research methods; comes with the literature review relevant to the stated topic; describes a formative assessment tool based on applying criteria and descriptors that could be implemented in the educational activities specific to the seminar classes within the university study programs with specializations in the field of Computer Science and ICT, but not only. The research's aim is to provide the university teachers and, not only, some methodological guidelines that would support them in developing and implementing a personal, descriptive tool for measuring the activity of the learner in the stated didactical circumstances.
\end{abstract}

Keywords: evaluation grid; evaluation tool; evaluation descriptors; evaluation criteria; authentic evaluation.

Rezumat. Prezenta lucrare se relevă a fi un studiu teoretico-aplicativ care se încadrează în dimensiunile științifice ale teoriei și metodologiei evaluării didactice. Autorul utilizează metode descriptive și analitice de cercetare; vine cu revizuirea literaturii de specialitate relevantă temei enunțate; descrie un instrument de evaluare formativă bazat pe criterii și descriptori care ar putea fi implementat în cadrul activităților educaționale specifice lecțiilor de seminar în cadrul programelor de studii de la specialitățile cu profesionalizare în domeniul Informaticii și TIC, dar nu numai. Scopul cercetării este de a oferi cadrelor didactice universitare, dar nu numai, unele repere metodologice care i-ar sprijini în elaborarea și implementarea unui instrument personal, descriptiv de măsurare a activității celui care învață în circumstanțele didactice enunțate.

Cuvinte-cheie: $\quad$ grilă de evaluare; instrument de evaluare; descriptori de evaluare; criterii de evaluare; evaluare autentică.

\section{Introduction and description of the research problem}

In the current grading sheet, implemented at Technical University of Moldova (TUM), there are several positions that document the dynamics of student success until the final test. 
Depending on the presence/absence of a year thesis in the discipline for which the list is completed, at the stage prior to the final evaluation, there are either 3 positions to be completed or 4.

In one of the formulas for calculating the final grade for a course for which no course year theses (there is a type of junior paper in the Republic of Moldova's universities) are provided previous of the final assessment, 4 grades appear, namely: periodic assessments 1 and 2; the current evaluation and the individual work of the student, for which according to the meaning of TUM, again the truncated average mark of the two evaluations is registered, of the current evaluation, but this time also of the individual work of the student.

In fact, the periodic evaluations $1 \& 2$ (we attest here an error regarding using of terminology) are organized and carried out strictly in accordance with the institutional documents for the management of the didactic process and, respectively, with the schedule established by the dean's office.

With the grading of the compulsory assessments $1 \& 2$, named by some internal documents of TUM as periodicals, and also with the grading of the individual work of the student the situation is relatively clear. But for us as tenured teachers remaining questions are:

(1.) How should we to give the grade for the current assessment?

(2.) What kind of formative components have to include the grade given during the current evaluation?

For teachers with major experience, it is not a problem to give a mark in that compartment. So that given grade should and will represents the cumulation of activities and / or student success as an overview of the course, seminar and / or laboratory lessons, individual work, degree of responsibility demonstrated level of creativity and complexity in solving problems distributed by the teacher; in some cases, even the attendance and the number of absences from lessons, etc. are taken into account.

In fact, other important points from the teacher's perspective can be mentioned here. Even if such a grading is successful and it is objective, there is a probability here that the student and / or the parent and / or the curator of the group etc. could have some questions about how the way in which given mark was established and what kind of indicators (most likely people interested in the fate of our student will use another expression) allowed the measurement and subsequent grading with a certain mark.

However, we consider necessary the existence of methodological indications that would facilitate the measurement and grading of student activity in teaching situations that do not end, literally, with the creation / issuance of a finished product, such as: oral speeches, frontal debates, oral argumentation (e.g.: choosing a solution, etc.), presentation and / or verbal explanation, participation in the didactic conversation, conference and / or interview, etc., most of the methods listed being applied to seminar classes, etc.

In this order of ideas, the purpose of our research is to provide the university teacher and, not only, some methodological guidelines that would support him in developing and implementing a personal, descriptive tool to measure the activity of the learner in teaching circumstances with predominant use of oral didactic methods.

Thus, in this paper we pursue the following objectives:

(1.) To analyze the current situation regarding the measurement and grading of the student's activity at the seminar classes from Faculty of Computers, Informatics and Microelectronics (FCIM), TUM; 
(2.) To propose and describe some solutions for measuring and grading the student's activity at seminar classes in the context of assessing / evaluating the knowledge of the student through oral communication methods in order to further implement in appropriate teaching situations.

\section{Review of the specialized literature}

\section{A. Notional fields and approaches related to didactic evaluation}

Confusions and / or inappropriate uses of terms related to forms of didactic evaluation are often encountered at the young teachers / parents / students and other categories of trainees. Over time, several researchers have tried to combat the incorrect use of notions related to didactic evaluation, motivating their research by various arguments. However, the basic one argument is the one formulated by Bill Ussher \& Kerry Earl (2010) made after the previous documentation from about 21 sources, some of which belong to:

- the main consultant of Evaluation Associates Ltd in Auckland, New Zealand Absolum, M. (2006; 2009);

- consultant, trainer and researcher in the field of didactic evaluation; the honorary alumna of PhD school at the University of Greenwich (2007) - Clarke, S. (2005; 2008).

The both researchers affirm: "[...] the common shortening of the full and meaningful terms, 'assessment for formative purposes' and 'assessment for summative purposes' [...] contributes to a confusion over assessments, information and methods, particularly for preservice teachers and those with less teaching experience.

By being well-informed about both purpose and assessment activity, teachers will have greater clarity in understanding, communication and practice regarding these important and useful concepts" [1].

Regarding the types of didactic evaluation, in general, these are classified according to criteria such as: the amount of verified information; objectivity of grading; the reference system for issuing value judgments on evaluated results (IVJER); evaluation agents; the moment when the evaluation is performed distinguishes three forms of it (see Figure 1).
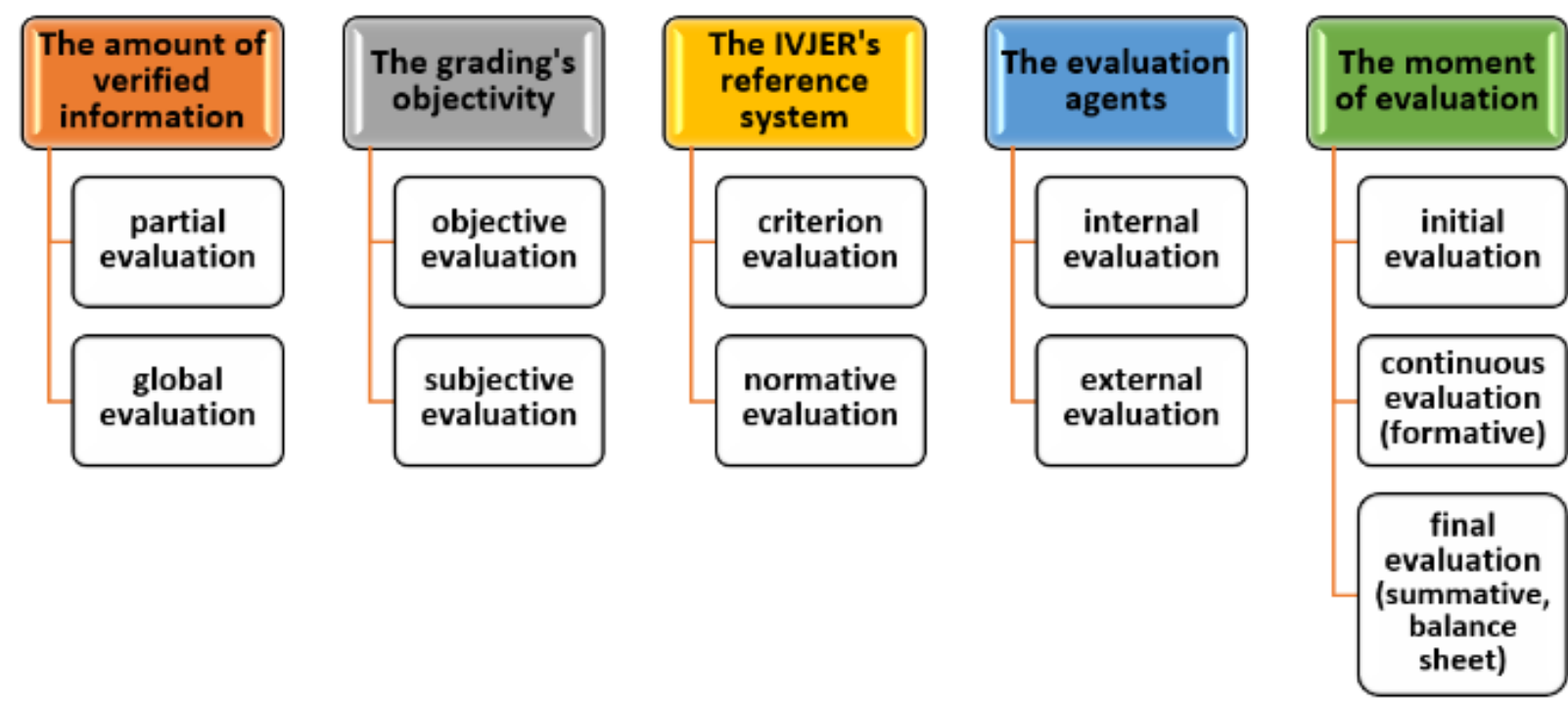

Figure 1. Taxonomy of didactic evaluations. 
Our study aims to implode some ambiguities regarding the implementation of the terms related to the time / moment when the evaluation is organized and carried out in a study discipline during the semester and / or year of studies. Besides the fact that the formative evaluation is different from the others by its placement in the order of succession in time within a course, it also has other distinctive features which make it to be different from a didactic and methodological point of view from other forms of evaluation (initial and / or summative).

Therefore, in accordance with the mode in which evaluation is integrated in an ongoing didactic process, we distinguish forms of evaluation that we can define as follows:

- The initial evaluation (assessment) is organized at the beginning of a learning cycle or study program and aims to determine the level of training of students. The initial assessment allows to determine the level of students' acquisitions in terms of knowledge, skills and abilities and aims to ensure the premises for achieving the objectives proposed for that stage.

- The formative (continuous) evaluation (assessment) accompanies the entire didactic path and is achieved through systematic verifications of knowledge of the study subject, the teaching of which is provided by the discipline curriculum in a certain interval / period of time for the entire student body, belonging to the same socio-academic units (same group, same torrent, same years, etc.).

- Summative or cumulative assessment (evaluation) is usually performed at the end of a longer training period (e.g.: chapter, module, semester, year of study, cycle of education, etc.), providing relevant information about the level of performance of students against objectives of the discipline stated in its curriculum.

Based on the arguments listed above, all evaluations are carried out in the time interval after the initial evaluation and before the final evaluation period, regardless of how these are called in the internal institutional documents, prepared by various universities, whether they are called periodic (term totally inappropriate), whether these are called current - however, these are formative or continuous!! By the way, the formative and continuous determinatives, in the context of didactic evaluation, are interchangeable, and the use of both of these versions is scientifically and methodologically correct.

\section{B. Authentic didactic evaluation: between concept and applicability}

Analyzing the new theoretical and methodological approaches to didactic evaluation, we encounter tangent ideas on how to carry out evaluations. Such a position accepted among researchers and teachers in the field of educational sciences has the idea of so-called authentic evaluation / assessments [2 - 8].

By www.merriam-webster.com: AUTHENTIC is an adjective; has given spelling and

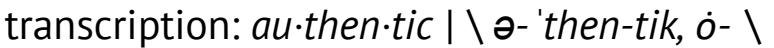

Definition of authentic: (1a): worthy of acceptance or belief as conforming to or based on the fact; e.g. paints an authentic picture of our society; (1b): conforming to an original so as to reproduce essential features; e.g. an authentic reproduction of a colonial farmhouse; (1c): made or done the same way as an original; e.g. authentic Mexican fare; (2): not false or imitation: REAL, ACTUAL; e.g. an authentic cockney accent; (3): true to one's own personality, spirit, or character; e.g. is sincere and authentic with no pretensions; (4a): of a church mode: ranging upward from the keynote; - compare PLAGAL sense $1 ;(4 b)$ : of a cadence: progressing 
from the dominant chord to the tonic; - compare PLAGAL sense 2; (5): obsolete: AUTHORITATIVE.

It seems that the given term has no meaning other than something valid, and is usually defined as something related to the actual world around it.

Some researchers expressed their views on the nature of authentic evaluation. Palm (2008) notes that this term is most often applied in contexts that have a tangent to truth and/or reality [9].

Bruce B. Frey Vicki L. Schmitt Justin P. Allen (2012) analyzes the vision of Palm (2008) pointing out that "[...] authenticity is defined as assessment that is real in terms of processes and products, assessment conditions or the presented context, and true to life beyond school, curriculum and classroom practice or learning and instruction" [10].

For example, one of the key points of the strategic plan of Deakin University (Australia) states that the role of the institution is to "[...] empower learners for the jobs and skills of the future [...]" (Deakin, 2014) and, because in this way "assessment drives learning", it is necessary to implement "[...] authentic assessment practices in higher education" [11].

Thus, according to us, the formative assessment, being a systemic and periodic one is organized in a certain interval of time to analyze and capitalize not only the knowledge, skills, and abilities of students, but also to report the results obtained in the course quality's evaluation, of study methods, of used didactic materials, and also other didactic components of the given discipline can and should meet the requirements of an authentic assessment (evaluation) both for methodological and scientific and ethical reasons (if we talk about the dimensions of relationships: teacher-student; student-student; student-teacher, etc.).

Particularly, during seminar classes, come into play the oral teaching-learningassessment methods, such as oral speeches, frontal debates, oral argumentation (e.g.: choosing a solution, etc.), exposition and / or verbal explanation, participation in the didactic conversation, conference, and / or interview, peer review, called also alternative assessment (evaluation) (all of these could be implemented both in the disciplines related to humanities and in the exact sciences' set of the disciplines by an oral presentation of public review, i.e. in front of fellow students), etc. Certainly, we consider, that the principles of genuine valuation should be taken into account during seminar classes.

By the opinion of Ofelia Oracion Flojo (2013) the lexical unit "authentic" involves measuring affectivity, skills and knowledge based on process and outcomes, and the lexical unit "assessment" involves measuring the knowledge competence based on outcomes [12].

In our opinion, in an authentic assessment, the student will be asked to apply the learned concept or theory on problem-solving / exemplifying real-life phenomena and / or to real conditions specific to a field of human activity. In other words, the real skills and / or performance of the learner will be implemented and, respectively, assessed. Thus, the authentic evaluation becomes an evaluation in which the student is asked to construct answers and / or to fulfill tasks that require more than the memory and / or reproduction of information and concepts.

As an idea, based on the practice of organizing and conducting evaluation activities, one of which, the TUM's version one, is described above, the number and frequency of assessment activities when students are graded by teachers, and the record of the learner's grades are made by both the parties - by the course holder and by his assistants - during the semester have the factor's effect of "[...] direct responsibility of the students [...] and outlining a fairer final grade" [13]. Certainly, these elements also transform a standard evaluation to 
corresponds to the principles of an authentic assessment. Given that in monitoring the student's academic success the dynamics and persistence of the learner are counted, as these denote student's learning and systemic involvement and, conversely, the appearance of good results sporadically speaks about their random effect (student learned once and/or has copied and/or has been helped by someone, etc.). In the context of the authentic evaluation's applying, our opinion is that the objectivity of the evaluation has to take into account not only the good and less good grades obtained by the student but also his responsibility, punctuality, and correctness. Given elements are no less important than all others in the long run.

So, how do we have to respond to our own assessment rigors so as to minimize or even eliminate controversial and confusing situations related to measuring and grading students' activity in seminar classes?

\section{Solutions for evaluation of students' activity during the seminar}

Even if the university institutions prefer to carry out the initial, formative, and final evaluations in written form versus oral form, there are oral didactic activities anywise predominate both in the social \& human disciplines and in the disciplines in the field of exact sciences in the seminar lessons. Although the exact disciplines focus mainly on solving exercises and problems from the scientific field to which the object of study is related, the students' oral communication competence is developed and capitalized here anyway. For example, in the seminar classes within the university disciplines such as - Fundamentals of Computer Programming, Data Structures and Algorithms, Advanced Programming Techniques, etc. - when the code writing is based on a formulated problem, it is very good to bring a few valid arguments, ask some clarification questions and insert unambiguous comments because through these we help students to implement the necessary algorithm and/or, conventionally speaking, to build that code. Similar situations often occur during laboratory lessons, guidance hours, etc. when the teacher initiates an interview with the student regarding some program sequences, etc. in order to evaluate the level of knowledge of the concepts by the student or to identify the originality of the presented and/or supported work.

Thus, in the didactic interaction teacher-student, student-student, student-teacher, the communication component is indispensable, and in the context of an authentic evaluation, this really cannot, but should not be avoided. Moreover, identical didactic situations happen many times during seminar lessons: questions are asked and answers are expected from the participants on both sides of the chair and everything, starting with an elementary answer to a question; presentation of a paper; writing a perfect (or less perfect) piece of code completely or partially, arguing the choice of a solution, using some disciplinespecific notions, etc. - all these should be verbalized. Given facts are a part of the didactic process and are related to the student's activity in the lesson which, like any other effort or demonstrated educational result, can and should be observed, evaluated, and ultimately graded by the teacher.

The subject of objectivity was not touched in vain. In general, in the case of grid tests and written papers, the student's work itself is material proof able to answer several questions when these arise as a result of disproof, ambiguities related to the objectivity of the assessment, and its grading. Our question is how do we cope when there are some ambiguities in the evaluation/grading of the student's activity during the seminar class, 
where not every learner necessarily gets to the blackboard or everyone equally interacts with the teacher or other course colleagues to solve problems/explanation of some solutions, etc. in the same lesson, especially as dynamics and persistence are important in authentic current assessment, just like in all seminar classes?

Or what is the purpose of the seminar lessons, these being passed as practical classes, if, as in the theory lessons, only the teacher speaks and explains? Teachers apply various strategies for organizing practical classes, but when these lessons lack lively interaction, fixed dialogue, the mental energy of the teaching process's actors gives rise to solutions here and now, mostly, the type of seminars where is done only the interrogation of homework, checking the studied subject, etc. - these kinds of classes are quite boring. So, teachers, really, try to be creative when possible. Obviously, with this objective in mind, the evaluation should be planned/executed and based on the principle of authentic evaluation: (1.) balancing the content of the evaluation activities \& items to be evaluated; (2.) impartiality towards the evaluated learner, but also (3.) the transparency of the grading process. One of the characteristics of objective and authentic evaluation is its transparency.

By Cosovan O. (2017) "[...] the evaluation requires the application of criteria that are known from the beginning, from the moment of formulating the task, the evaluated learners too" [14].

In its classic version, the one that satisfies the conditions for elaborating written evaluations either of grid type or of case study type, essay, thesis, etc. are applied the analytical scales and given practice is already one unanimously accepted by the representatives of the Republic of Moldova's educational system. Therefore, according to the development methodology of the written evaluation, the author of the evaluation subjects is the person who specifies the scoring method.

We share the opinion of Cosovan O. (2017) as that "[...] the evaluation of oral communication acts is accompanied by observation grids, but also by numerous difficulties. First of all, this is a time-consuming process; [...] in the second, the topics for speeches must be varied, while maintaining the same degree of difficulty; thirdly, the debriefing of the speech, if it is not recorded, reaches moments of mistrust: the evaluated person questions the interpretation of the own speech and declares that he would not have said such a thing, etc." [ibidem].

The communication, hence and the evaluation of the didactic activity of the students in the oral form are natural and indispensable at the seminar classes for the whole range of academic disciplines (and those related to the humanities, but also those related to the exact sciences), even if the written evaluations are in the top of the preferences of the teachers, but also of the students. Moreover, the originality of the student's work and / or the depth of his arguments regarding the choice of a solution or the application of an approach in case of implementing an algorithm and, subsequently, the writing of a code sequence related to the studying of programming languages' disciplines, such as the professionalization courses from FCIM, TUM, can be detected only through an additional interview.

Just because we do not know or are confused about how to evaluate such a student activity does not mean that it should be treated superficially and / or ignored either by the absence of grading or by uniform grading of all students with the same marks, regardless of whether it happens in the same lesson or at the end of the course, when the mark should appear near of the learner's name and should reflect the degree of his involvement and success in such activities. 
In our vision, the different forms of oral activity - individual speeches, interviews, group discussions, interventions that correct and / or that come with clarifications on the speech of another person (colleague and / or teacher), presentation of papers, public presentation of case studies, or research, interviews, etc. - have an added formative value from the perspective of reaching the didactic finalities by the student, and also for the group cohesion's formation; developing the ability to build collaborative communities for students (a collaboration of professional one day).

We believe that all oral forms of educational activities, and also the results of the didactic interaction should be taken into account. Respectively, these require an evaluation no less rigorous than the written tests, in particular, because the activities and didactic interaction supported by oral methods are an integral part of the contract hours provided by the curriculum of the academic discipline.

The basic criteria for evaluation of the predominantly oral activity of the student in the seminar classes are, in general, common for several categories of products resulting from the educational activity.

These include: (1.) the compliance with the task; (2.) the scientific correctness of the statement/the validity of the argument; (3.) the correctness of the language and the correct use of subject-specific terms and dictionaries; (4.) the accuracy of code writing (applicable in the learning of all possible programming courses. Another relevant criteria should be stipulated in the study of other courses); (5.) the observance of the temporary volume of the speech (it depends on the situation; it may depend on the complexity of the problem).

For the score to be offered for each criterion to be evaluated, it should be presented gradually (e.g.: through a grid, having a certain scale (either from 0-10 or from 0-5, etc.)) by means of explicit descriptors against which the student's grade can be marked according to the level of knowledge/degree of development of the competencies reflected by the criterion in question.

For example, we have at our disposal 5 criteria for evaluating the student's activity during the seminar lesson at a certain course, where the didactic subject focuses on the study of one or more programming languages and/or technology ( $\mathrm{C} / \mathrm{C}++, \mathrm{C \#}$, Java, Python, etc.) or other computer science-related technologies, through which specific source code will be developed.

In order to illustrate how to provide the final scores to one or more students during this type of activity in the seminar classes, we will simulate a teaching situation, namely:

(1.) There is the problem to be solved is formulated frontally in the given lesson.

(2.) The teacher also uses oral methods, such as oral speeches, frontal debates, oral argumentation, group expertise, brainstorming, the argumentation of the proposed solutions to solve the problem / exercise, etc. for the subsequent demonstration of its solution.

The modeled didactic situation is complex also from the point of view of the educational approach, and also from the perspective of the intellectual involvement of the students.

(3.) As a solution, we could develop a more or less detailed grid that will help the evaluation, grading the student's activities, and later, if it is necessary to argue the grade by selecting / providing a score corresponding to the level of knowledge / skills developed by the evaluated one. 
For example, we found very original solutions for the development of tools for evaluating spoken speech [ibidem]. Although these suggestions are formulated for the needs of courses related to the philology teachers' professionalization, some ideas can be adopted and applied to subjects other than social humanities, while other ideas can be taken almost the same way. In our view, this is a grid that evaluates the quality standards of arguing the ideas/solutions proposed by the learners.

The following grid of descriptors (see Table 1 ) can be implemented in seminars to academic disciplines related to the study of exact sciences after a slight adaptation of the ideas presented above:

Table 1

Descriptors for student's arguments evaluation

\begin{tabular}{llc}
\hline $\begin{array}{l}\text { Ord. } \\
\text { num. }\end{array}$ & Descriptors' content & Given score \\
\hline & \multicolumn{1}{c}{ Evaluation of the argumentation by S } \\
\hline 1. & $\begin{array}{l}\text { S formulates arguments in connection with the discussion; the } \\
\text { arguments are original. }\end{array}$ & 5 \\
\hline 2. & S makes valid and logical arguments, but without originality. & 4 \\
\hline 3. & S's argument is logical but incoherent and confusing. & 3 \\
\hline 4. & $\begin{array}{l}\text { S brings arguments with uncertain validity; the arguments put } \\
\text { forward do not support the expressed point of view. }\end{array}$ & 2 \\
\hline 5. & $\begin{array}{l}\text { S tries to argue, but what he proposes is not an argument for the } \\
\text { expressed opinion (or the expressed opinion is missing). }\end{array}$ & 1 \\
\hline 6. & S makes no arguments. & 0 \\
\hline
\end{tabular}

The evaluation grid of the criteria for understanding the subject of the discussion can be implemented with a slight modification of the original solution, as follows (see Table 2):

Table 2

Descriptors For Evaluation Subject Comprehension by Student

\begin{tabular}{|c|c|c|}
\hline $\begin{array}{l}\text { Ord. } \\
\text { num. }\end{array}$ & Descriptors' content & Given score \\
\hline \multicolumn{3}{|c|}{ Evaluation of the comprehension of the subject by $\mathrm{S}$} \\
\hline 1. & $\begin{array}{l}\text { S launches new and contradictory interpretations of the subject. S } \\
\text { makes sure to concretize the topic and to bring the discussion back } \\
\text { to the formulated topic if he feels a deviation. }\end{array}$ & 5 \\
\hline 2. & S explain the topic and return to the formula under discussion. & 4 \\
\hline 3. & $\begin{array}{l}\text { S repeats what your colleague said, but did not add value to the } \\
\text { content or depth of the idea (treads water). }\end{array}$ & 3 \\
\hline 4. & S demonstrates a unilateral understanding of the subject. & 2 \\
\hline 5. & $\begin{array}{l}\text { S deviates from the subject to irrelevant things. S proves a simple } \\
\text { understanding of the subject that is not suitable for age. }\end{array}$ & 1 \\
\hline 6. & $\begin{array}{l}\text { S does not prove an understanding of the subject. The S's } \\
\text { interventions are either missing or detached from the subject. }\end{array}$ & 0 \\
\hline
\end{tabular}


Given the fact that during this paper we try to describe the development of a methodological tool able to capitalize the didactic evaluation grids based on descriptors, which correspond to the principles of an authentic evaluation, we will exemplify its implementation through a possible live coding (LC) ${ }^{2}$ activity. This type of activity is usually implemented in the seminar classes from the study programs within FCIM, TUM.

The product of the teaching activity intended for evaluation can be written either directly (1) on the blackboard or (2) projected on a multimedia screen or (3) broadcasted during an online lesson through an app working in videoconference mode. The set of listed methods reproduces the use of the blackboard as a frontal didactic method.

There is proposed the following evaluation tool here (see Table 3):

Table 3

Descriptors for evaluation the code's writing by student

Ord.

num.

Descriptors' content

Given score

\section{Quality evaluation of the code's elaboration by $\mathrm{S}$ \\ (Live coding commented by S)}

$S$ writes the impeccable code from the perspective of the proposed

solution both syntactically and logically (semantically) in full

1. compliance with the condition of the problem and the algorithm

to be implemented. The arguments and comments in the written code are clear and absolutely correct!

$S$ can make slight deviations in formulation, concepts' use, argue of ideas, but self-correct (or correct your colleague) very quickly in all situations related to the code's development.

$S$ proposes alternative solutions without deviating from the given

2. problem's formulation (if he deviates, he returns easily to the subject of the problem).

$\mathrm{S}$ can make slight deviations in formulation, concepts' use, argue of ideas, but self-correct (or correct your colleague) very quickly in all situations related to the code's development.

$S$ explains the proposed solution at the code level, but does not propose any alternative solutions (either syntax or algorithm); makes some deviations from the formulated condition of the problem.

3. If $\mathrm{S}$ deviates, he does not return to the subject independently.

$S$ demonstrates a one-sided understanding of the problem.

$S$ writes the code with the direct involvement of the teacher/colleagues; the code is perfected with the help of the teacher/colleagues along the way; the written code has a lot of corrections, but it is a functional one.

\footnotetext{
2 Live-coding, also called on-the-fly programming, is an interactive method of presenting the process of real-time code writing, accompanied by verbal cues and explication of programming tasks. Thus, the programming process represents only an integral part of another, more complex process, in which the running of the elaborated code will follow. LC is also used as a teaching method in the study of programming languages and techniques.
} 
Continuation Table 3

$S$ repeats the ideas presented by colleagues, but formulates them awkwardly, with mistakes in the use of concepts, the sequence of writing / developing the source code (even though the solution is dictated, he cannot translate it into the syntax of the used programming language).

4. S showed a superficial understanding of some fragments of the problem. $S$ denotes a lack of understanding of the integrated condition of the problem.

Written code by $S$ is done with syntactic errors; although the simple as complexity code sequences are written correctly (or almost correctly).

$S$ deviates from the subject to irrelevant things; $S$ demonstrates improper (aberrant) use of terms. S proves the simplistic, age-

5. inappropriate understanding of the subject.

The attempt to write code by $S$ is done with numerous syntactic errors, even on the simple, as complexity, fragments of code.

$S$ does not demonstrate an understanding of the subject. The

6. interventions are missing or detached from the subject. The written "code" is no code at all!

7. S is quiet, does not say anything \& writes nothing.

\section{Conclusions}

The idea of implementing such grids to facilitate and make transparent the assessment carried out by the teacher, using descriptors, can be extended and / or customized to assess other types of educational activities or to measure dimensions of learning and / or demonstrate observable skills, which are more difficult to remember and document (as is the case of written works).

These kinds of grids in traditional or electronic format (created with tools like Google Forms, Online Quiz Makers, etc.) can be offered to a group of students for peer evaluation in other teaching activities where collaborative methods such as organizing competitions / public presentations of learning outcomes, etc.).

We consider that documenting student activity through a descriptor evaluation grid transforms the didactic evaluation supported by oral communication methods into one that meets the principles of authentic evaluation because it comes with the correct, objective, real-time quantification of the evaluator's performance, which amplifies the evaluation value to the class, the credibility of its objectivity, offering involuntarily to the evaluated one a feedback regarding his answer (the feedback is included even in the body of the evaluation tool, in descriptors).

Although the use of such a detailed tool with criteria, indicators, and descriptors obviously requires time and effort on the part of the teacher or other evaluators, we recommend the implementation of such grids in evaluating students' activity in seminar classes, especially just in this way, according to Cosovan O. we and students can have "the certainty of an objective assessment" [ibidem]. 
Acknowledgments. The work has been presented at the International Conference on Electronics, Communications, and Computing, ECCO - 2021 (October 22, 2021).

\section{References}

1. B. Ussher B., Earl K. 'Summative' and 'Formative': Confused by the Assessment Terms? [online]. Available: In: New Zealand Journal of Teachers' Work, vol. 7, Issue 1, 2010, pp. 53-63. [Accessed: 15.08.2021]: https://researchcommons.waikato.ac.nz/handle/10289/4845

2. Archbald D.A., Newmann F.M. Beyond standardized testing: Assessing authentic academic achievement in the secondary school. [online]. Available: In: Washington, DC: Office of Educational Research and Improvement, 1988. [Accessed: 15.08.2021]: https://files.eric.ed.gov/fulltext/ED301587.pdf

3. Bergen D. Authentic performance assessments. [online]. Available: In: Childhood Education, 70(2), 19931994, pp.99-102. [Accessed: 17.08.2021]: https://www.tandfonline.com/doi/abs/10.1080/00094056.1993.10521005

4. Gronlund G. Focused early learning: A planning framework for teaching young children. [online]. Available: In: St. Paul, MN: RedleafPress, 2003. [Accessed: 18.08.2021]: https://eric.ed.gov/?id=ED473928

5. Meyer C. What's the difference between authentic and performance assessment? [online]. Available: In: Educational Leadership, 49(8), 1992, pp. 39- 40. [Accessed: 15.08.2021]: https://files.ascd.org/staticfiles/ascd/pdf/journals/ed_lead/el_199205_meyer.pdf

6. Newman F., Brandt R., Wiggins G. An exchange of views on semantics, psychometrics, and assessment reform: a close look at 'authentic' assessments. [online]. Available: In: Educational Researcher, 27(6), 1998, pp. 19-22. [Accessed: 17.08.2021]: https://journals.sagepub.com/doi/pdf/10.3102/0013189X027006019

7. Wiggins G. Teaching to the (authentic test). [online]. Available: In: Educational Leadership, 46(7), 1989, pp. 41-47. [Accessed: 17.08.2021]: https://files.ascd.org/staticfiles/ascd/pdf/journals/ed_lead/el_198904_wiggins.pdf

8. Wiggins G. A true test: Toward more authentic and equitable assessment. [online]. Available: In: Phi Delta Kappan, 70(9), 1989, pp. 703-716. [Accessed: 18.08.2021]: https://grantwiggins.files.wordpress.com/2014/01/wiggins-atruetest-kappan89.pdf

9. Palm T. Performance assessment and authentic assessment: A conceptual analysis of the literature. [online] Available: In: Practical Assessment, Research and Evaluation, 13, 4, 2008, pp. 1-11. [Accessed: 18.08.2021] https://scholarworks.umass.edu/cgi/viewcontent.cgi?article=1201\&context=pare

10. Frey B. B., Schmitt Justin V. L., Allen P. Defining Authentic Classroom Assessment. [online]. Available: In: Practical Assessment, Research, and Evaluation, Volume 17, 2012. [Accessed: 15.08.2021]: https://scholarworks.umass.edu/cgi/viewcontent.cgi?article=1245\&context=pare

11. Sridharan B., Mustard J. Authentic Assessment Methods: A Practical Handbook for Teaching Staff. [online]. Available: In: Part-I. Deakin University, 2016. [Accessed: 17.08.2021]:

https://www.researchgate.net/publication/289996648_Authentic_Assessment_Methods_A_Practical_Handbo ok_for_Teaching_Staff_Part-I_Deakin_University

12. Flojo O. O. Curriculum and Instruction: The Teacher of English. In: USA, The Teacher Education Council, Department of Education, 2013.

13. Burlacu N. Evaluation on Moodle: from idea to application. In: Burlacu, N., Ababii, V., Ciorbă, Dm., etc., Solutions for online studies in engineering education at the university. Good practice guide: From the experience of FCIM teachers. Publishing House „MS Logo“, Chisinau, 2021, pp. 70-85 (in Romanian).

14. Cosovan O. The Group Discussion as an Oral Assessment Task. In: Didactica Pro... Journal of educational theory and practice, 2017, December, Nr.5-6 (205-106), pp. 58-62 (in Romanian). 